\title{
FOOD OFFERED TO IDOLS \\ IN 1 CORINTHIANS 8-10 1
}

\section{Derek Newton}

This thesis investigates the conflict which existed in Corinth around the mid-first century C.E. concerning Christian involvement in cultic meals. Scholarly attention has focused either on detailed exegesis of Paul's teaching in 1 Corinthians 810 or on Greco-Oriental cultic meal evidence from Classical and Hellenistic times. Little attention has been paid to the nature and dynamics of the sacrificial food issue itself, or to the available evidence of Imperial Cult which so dominated Roman Corinth in the early Christian era. Scholarship has paid insufficient attention to the conflicting viewpoints of the Corinthians themselves concerning food offered to idols.

Fundamentally, the sacrificial food issue was a missionary problem which forced Paul into cross-cultural communication in an attempt to define the actual nature of idolatry, worship and Christianity in Corinth. Those entering Christianity from a so-called 'pagan' religion would not have done so with a clean break from previous religious convictions. The believers' religious background is crucial in any attempt to unravel the reasons why the problem of sacrificial food was so intractable at Corinth. (Chapter 2 identifies a contemporary case-study of cultic meals among the Torajanese people of South Sulawesi in Indonesia.)

The bulk of this thesis is concerned with the immediate context into which Paul addressed his first Corinthian epistle. Consideration of the archaeological evidence (chapter 3) shows that it is impossible to confirm that the cults of Demeter/Kore, Asclepius, Isis/Sarapis and the cults of the dead operated

\footnotetext{
${ }^{1}$ Derek Newton, Food Offered to Idols in 1 Corinthians 8-10: A Study of Conflicting Viewpoints in the Setting of Religious Pluralism in Corinth (unpublished Ph.D. thesis, University of Sheffield, 1996); supervisor: Dr. Loveday C.A. Alexander.
} 
dining facilities at the time that Paul wrote the epistle. Whilst these cults must not be ignored, this thesis argues that serious attention ought to be given to Roman Imperial Cult as a context for the issues dealt with in the Corinthian Correspondence.

Chapters 4 and 5 present detailed primary source materials concerning images, sacrifices and communal meals, the evidence being derived mostly from literary sources, inscriptions and papyri. The main focus of Chapter 4 concerns the nature and perceived significance of images. The term $\varepsilon$ " $\delta \omega \lambda$ ov is consistently translated as 'idol' by the RSV, yet it is used in the New Testament to refer to varying practices. It is suggested that some Corinthians, because of their different backgrounds, understood $\varepsilon i \delta \omega \lambda$ ov and similar terms in ways different from those in which Paul himself understood and communicated them. If we can detect problems in defining 'idol', then ipso facto there are likely to be problems in defining 'idolatry' itself and problems also, therefore, in setting boundaries to Christian involvement in such 'idolatry'.

The normal pre-Christian Greco-Roman understanding of $\varepsilon$ i $\delta \omega \lambda$ ov lay in the realm of the dead/ghosts/phantoms rather than the divine, and was understood primarily to be an image. The term $\varepsilon$ i $\delta \omega \lambda$ ov consistently involves a negative and polemical condemnation, yet without a detailed description or appraisal of what such worship actually involved. There was potential for misunderstanding between Paul and the Corinthian believers in this regard, and particularly so when it concerned the perceived nature and significance of the Roman Emperors.

Evidence of Sacrifices and Communal Meals in chapter 5 reveals the sheer complexity of the problem. The term $\varepsilon i \delta \omega \lambda$ ó $\theta v \tau$ ov could refer not only to the sacrificial offering itself but also to the consumed food. Linguistically, the sacrifice and the meal constituted an inseparable unity, thus raising the issue of what food at a ceremony actually was considered 'sacrificial'. Nor were the intended recipients of the offerings easily definable. The $\varepsilon i \delta \omega \lambda$ ó $\theta v \tau o v$, once held to be the exclusive preserve of Olympian gods, has now been identified in ceremonies to chthonic deities and semi-divine ancestral spirits. Even the perceived function of sacrifices was not limited to the 
establishing of relations with supernatural powers and the invoking of response from the them. Sacrifice was also a means of fulfilling socio-political functions, as well as a way of expressing custom and tradition. Significant evidence was found that the act of sacrifice itself tended to be the duty of a small group of appointed officials. As far as the actual meal was concerned, meals not only held 'religious' significance, but simultaneously were considered to act as markers of socioeconomic class divisions, as opportunities to converse and build friendships, and as means of fulfilling socio-political obligations.

Because of the complex, multi-faceted nature of images, sacrifices and communal meals, any attempt to define and demarcate the actual boundaries of 'idolatrous worship' was fraught with difficulty. Chapter 6 of the thesis argues that very little of 1 Corinthians 8-10 actually deals with the practicalities of sacrificial food per se; instead, it is primarily concerned with moulding attitudes. One of the keys to understanding Paul's strategy lies in 8:1 in which the apostle writes: 'Now concerning food offered to idols: we know that "all of us possess knowledge".' This 'knowledge' has been linked by scholars to the issue of Gnosticism, but such lines of argumentation are red herrings. The apostle rather is referring to the wide range of 'knowledge' and individual positions/interpretations in the church regarding the issue of sacrificial food. Confronted by such a complex dilemma, Paul develops general principles which are designed to lead his readers away from their own entrenched individual 'knowledge' and viewpoints and towards concern for the Christian community. The apostle thus employs a protracted series of arguments, each of which calls believers to adopt caring, communal attitudes that look beyond self-interest: the priority of love (8:1-3); the conscience of the weaker brethren (8:7-13); setting aside rights for the sake of the Gospel and of those without Christ (9:1-18); sacrifice of individual identity for the sake of the Gospel (9:19-23); selfdiscipline for the sake of the Gospel (9:24-27); threats to the corporate life of the people of God (10:1-13); partnership with Christ and His community (10:14-22); building others up (10:23$24)$; concern for the other's conscience (10:25-30); concern for 
God's glory, the church of God, the advantage of many and imitation of Christ (10:31-11:1).

Finally, as regards specific teaching on the practicalities of sacrificial food, the thesis tackles the thorny controversy of the apparent contradiction between Paul's view in 1 Corinthians 8 and 10:14-22. The former passage seems to claim that an idol was something of little or no consequence, whereas the latter passage speaks of offerings to demons. 1 Corinthians 8 appears to convey Paul's neutral or positive view of eating in a temple context, subject to the need for consideration of the weak, whereas 1 Corinthians 10:14-22 portrays a highly negative position that places a total ban on participation.

There is no need to posit the idea that chapter 8 concerns 'social' meals, whilst chapter 10 deals with 'religious' meals; the text suggests no such distinction; nor is such a division realistic in the ancient world context. Paul was in effect forbidding the consumption of food in places of images in 8:113. Such a position immediately reduces the supposed tension between 8:1-13 and 10:14-22. Moreover, whilst the emphasis of chapter 8 is on the consumption of food by those reclining, chapter 10 introduces a new note, namely idolatry and the danger of becoming idolaters. Thus, both background and exegetical grounds, Paul does indeed set an absolute behavioural boundary line in 10:20-22 which believers must not transgress. In short, believers must never themselves make an actual sacrificial offering. To have done so would have been perceived as leading other believers to participate in a meal initiated by a Christian believer offering a 'pagan' sacrifice. Such an act would have made a complete nonsense of believers belonging to the communion of Christ so emphasised by Paul in 10:143-22. Such an act at a cultic festival would have destroyed the distinctiveness and credibility of the church of Christ in Corinth. After all, it was 'pagan perception' and reception of the Gospel which was consistently uppermost in the apostle's mind. 